\title{
Pengembangan Daerah Pariwisata Melalui Pemanfaatan Upacara Adat Rambu Solo Kabupaten Toraja Utara James Rilatupa ${ }^{1}$, Uras Siahaan ${ }^{2}$, Margareta M. Sudarwani ${ }^{2}$
}

123 Universitas Kristen Indonesia, Jakarta, Indonesia

Email; jedrilatupa@gmail.com, urassiahaan@yahoo.com, margareta.sudarwani@uki.ac.id

\begin{abstract}
Abstrak
Upacara penguburan telah menjadi ikon yang sangat penting bagi pariwisata di Toraja, terutama Toraja Utara. Seluruh perhatian penduduk, termasuk Pemerintah Daerah Toraja Utara akan terpusat kepada kegiatan ritual ini. Bangunan Rumah (Tongkonan) dan Lumbung Padi (Alang) tetap terpelihara dan dijaga untuk melaksanakan upacara tersebut, sehingga keberadaan Rumah tradisional tersebut tetap terjaga keberlanjutannya. Dalam penelitian tentang pelestarian bangunan upacara pemakaman ini telah disampaikan prinsip konservasi dan revitalisasi bangunan upacara tersebut. Dalam Kegiatan Pengabdian Pada Masyarakat, tim PPM Program studi Magister Arsitektur PPs UKI telah dilakukan beberapa penyuluhan tentang masalah konservasi dan revitalisasi KomplekUpacara Pemakaman tersebut. Tradisi upacara pemakaman tersebut juga membawa dampak negative pada pemakaian lahan yang luas, masalah pelestarian lingkungan dan penggunaan bahan bambu yang tidak terbatas, yang seharusnya dapat dilestarikan dan dibudidayakan. Selain itu juga, teknik perawatan bangunan dan pemakaian bahan lain yang lebih berkelanjutan akan menjadi salah satu cara pelestarian dan budidaya tanaman bambu. Dengan pengembangan teknik membangun dan system pelaksanaan pemakaman, maka tradisi ini tetap akan terpelihara dan biaya upacara pemakaman dapa tmenjadi alternative penghematan biaya upacara pemakaman.
\end{abstract}

Kata Kunci: Upacara Pemakaman, Pelestaran Bangunan dan Rambu Solo.

\begin{abstract}
Burial ceremonies have become very important icons for tourism in Toraja, especially North Toraja. All the attention of the population, including the North Toraja Regional Government will be focused on this ritual activity. Houses (Tongkonan) and Lumbung Padi (Alang) buildings are maintained and maintained to carry out the ceremony, so that the existence of these traditional houses is maintained. In research on the preservation of the burial ceremony building, the principles of conservation and revitalization of the ceremonial building have been conveyed. In Community Service Activities, the PPM team of the UK PPs Masters of Architecture Study Program has conducted several counseling on issues of conservation and revitalization of the Funeral Complex. The funeral ceremony tradition also has a negative impact on the use of vast land, the problem of environmental preservation and unlimited use of bamboo material, which should be preserved and cultivated. In addition, building maintenance techniques and the use of other materials that are more sustainable will be one way to preserve and cultivate bamboo plants. With the development of building techniques and funeral implementation systems, this tradition will continue to be preserved and the cost of the funeral can be an alternative to saving the cost of the funeral
\end{abstract}

Keywords: . Funeral Ceremony, Building preservation, Rambu Solo 
Volume 2, Nomor 1, Tahun 2020 Hal 330 - 338

\section{PENDAHULUAN}

Rumah Tongkonan Toraja Utara di Sulawesi Selatan, yang berupa bangunan monumen maupun bangunan rakyat, menyimpan warisan budaya yang tak terkira nilainya. Bukan hanya dari segi perwujudan arsitekturalnya saja, namun juga dari segi kekayaan ilmu pengetahuan konstruksi bangunan. Ketangguhan Rumah tongkonan di Toraja Utara telah teruji oleh tantangan alam selama ratusan tahun. Upaya pelestarian telah dilakukan oleh Pemerintah Indonesia melalui pemerintah daerah setempat, dengan diterbitkannya Undang-Undang RI No.11 tahun 2010 tentang Cagar Budaya yang merupakan pembaharuan dari UndangUndang RI No.5 tahun 1992 tentang Benda Cagar Budaya.

Penyuluhan tentang Konservasi Lahan Dan Bangunan Kompleks Upacara Adat Rambu Solo' (Studi Kasus Upacara Adat Rambu Solo' Di Siguntu Kabupaten Toraja Utara Sulawesi Selatan) diawali dengan penelitian perdana tentang upacara adat Rambu Solo' di Toraja Utara yang dilakukan oleh peneliti pada tahun 2017 di rumah dinas Bupati Toraja Utara Bapak Kalatiku Paembonan. Penyuluhan ini mendapat sambutan hangat dan dukungan dari Bapak Bupati Toraja Utara, Bapak Kalatiku Paembonan. Pada tahun 2020 Penelitian tersebut dilanjutkan, dengan penekanan pada pengembangan Rambu Solo sebagai Sebagai sambungan atau lanjutan dari penelitian pertama tahun 2017 maka pada tanggal 12-19 Januari 2020 tim peneliti melakukan penyuluhan kembali terkait upacara adat Rambu Solo' di Toraja Utara.

Masyarakat Toraja mencurahkan banyak waktu dan upaya untuk merawat nenek moyang mereka dengan menggunakan upacara pemakaman adat yang rumit yang diselingi dengan arak-arakan dan tontonan penyembelihan kerbau, babi, rusa dan semua hewan yang ada di daerah tersebut. Masyarakat Toraja percaya bahwa leluhur yang tinggal di surga akan berpartisipasi langsung dalam kesejahteraan dunia lewat berkat mereka. Upacara ini mengandung nilai ritual memandang hubungan transendental relasi manusia dengan pencipta, menggambarkan konsep alam semesta, serta mengantarkan pada perpindahan alam dunia. Rangkaian Upacara Pemakaman Rambu Solo dimulai dengan Tarian Ma'badong. Rambu Solo sendiri berarti pesta adat pemakaman masyarakat Toraja yang memiliki makna mengantarkan arwah ke tempat peristirahatannya. Untuk masyarakat Toraja, kematian bukanlah sesuatu yang ditakuti, sebaliknya harus dirayakan, karena berarti mengantarkan seseorang ke alam barunya setelah menyelesaikan waktu hidup di dunia.

Toraja merupakan suku yang hidup di Kabupaten Toraja Utara yang memiliki upacara pemakaman adat yang paling terkenal, meski upacara pemakaman adat ini semakin berkurang. Kabupaten Toraja Utara sangat terkenal dengan obyek-obyek pariwisata yang sangat unik, selain upacara pemakaman adat, ada Rumah Adat 
Volume 2, Nomor 1, Tahun 2020 Hal 330 - 338

Tongkonan, Kuburan Leluhur di Gunung, Negeri di Atas Angin, dan lain-lain. Kemahsyurannya telah terdengar jauh puluhan tahun yang lalu, tetapi kehebatan tersebut tetap tidak bisa mengalahkan ketenaran Pariwisata di Bali dan Danau Toba sampai saat ini, sehingga dalam menentukan arah pariwisata, destinasi turis di Indonesia, Daerah Toraja tidak dimasukkan. Hal ini cukup memprihatinkan dan perlu perhatian serius dari pemerintah daerah. Sehingga untuk mempertahankan dan mengembangkan daya tarik upacara pemakaman adat Toraja sebagai tumpuan destinasi wisata, perlu melakukan penelitian untuk manganalisa dan mengidentifikasi upacara pemakaman adat Toraja.

Penggunaan jenis material bambu pada rumah tongkonan yaitu kombinasi dari jenis bambu betung dan jenis bambu gombong.penamaan jenis material bambu pada tiap daerah tanaman dapat berbeda beda.Permasalahan yang umum terjadi adalah kurangnya perhatian pemeliharaan dan perawatan pada pasca pemasangan material atap bambu sehingga pada waktu tertentu dapat mengakibatkan tumbuhnya tanaman liar pada permukaan atap bambu.

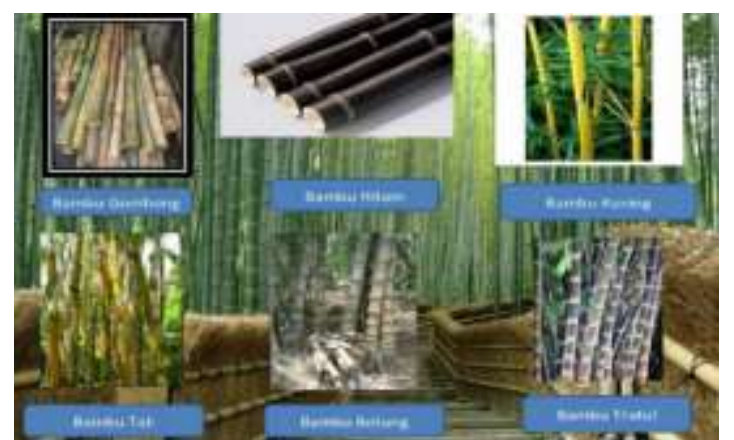

Gambar 1. Jenis-jenis bambu di Indonesia

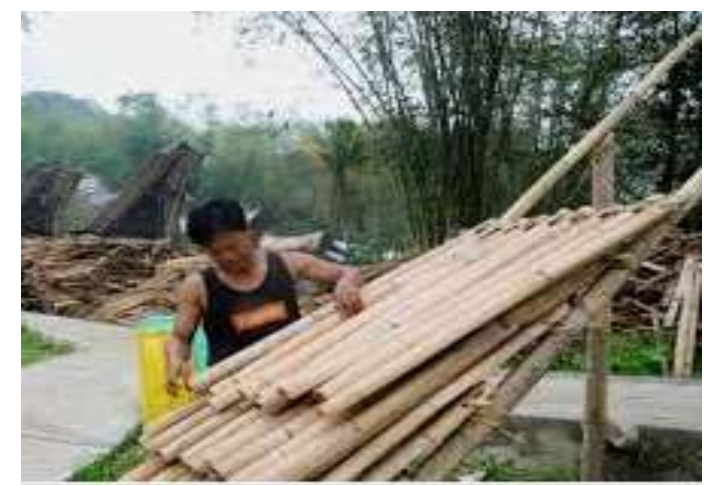

Gambar 2. Pemasangan atap bambu

\section{Perumusan Masalah}

Permasalahan upacara pemakaman adat Toraja yang menelan biaya sangat besar dan adanya pemakaian lahan pertanian dan pemakaian bahan bangunan yang membutuhkan tenaga dan biaya yang besar pula dan sekali pakai di satu sisi. Kondisi upacara pemakaman adat yang masih menjadi tumpuan daya tarik wisata Toraja disisi lain. Merujuk pada latar belakang di atas muncul pertanyaan penelitian yaitu:

1. Dengan adanya penemuan beberapa rumah tongkonan didesa palawa yang mengalami kerusakan akibat serangan rayap maupun rumah tongkonan (konstruksi lapuk) yang roboh akibat angin kencang. diperlukan program pada Pemeliharaan dan perawatan rumah tongkonan dengan cara tradisional dapat menggunakan bahan alami Bagaimanakah konservasi lahan, rekayasa material bangunan pemakaman Rambu Solo, Toraja?

2. Bagaimanakah cara meningkatkan pemanfaatan lahan dan bangunan situs pemakaman Rambu Solo 
Volume 2, Nomor 1, Tahun 2020 Hal 330 - 338

3. Pelestarian lingkungan, melalui penggunaan yang kurang dikembangkan, sesuai dengan standar kesehatan lingkungan serta laju penurunan kondisi lingkungan sekitar terbangun area permukiman penduduk sehingga habitat kehidupan rayap terganggu sehingga menjelajah mencari makanan pada rumah tongkonan dan rumah rakyat yang berbahan kayu

\section{METODOLOGI PERANCANGAN}

Diperlukan beberapa cara untuk pemeliharaan dan perawatan rumah tongkonan. Antara lain Metode berupa tembakau, cengkeh yang direbus dan direndam selama $2 \times 24$ jam serta di oles dengan pelepah pisang dalam setahun sekali.Cara tradisional lain adalah dengan metode pengasapan.

Proses pengawetan material bambu sebelum dan sesudah pemasanganKonstruksi atap rumah tongkonan perlu dilakukan secara berkala. Selanjutnya penggunaan material konstruksi kayu dimasa mendatang sebaiknya tidak menebang kayu solid/biasa kelas kuat 1 tetapi dapat berinovasi menggunakan kayu tebangan kelas rendah dengan dilakukan rekayasa pemadatan,komposit bahan kayu serta bentuk produk laminasi kayu yang dapat setara kekuatan nya dengan kayu solid kelas kuat 1.

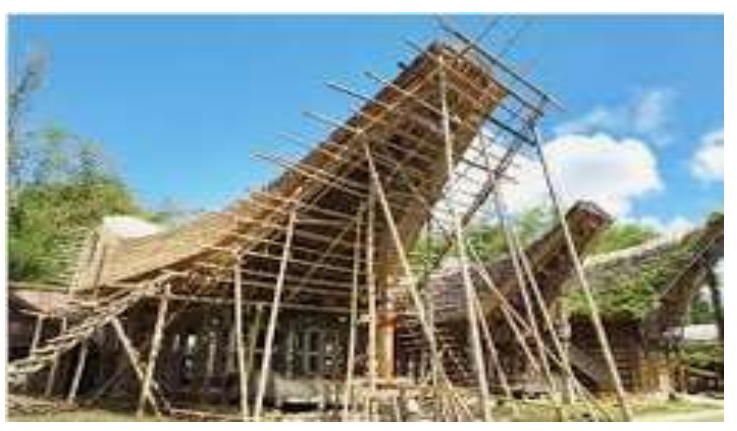

\section{Gambar 3. Pekerjaan rumah adat Tongkonan}

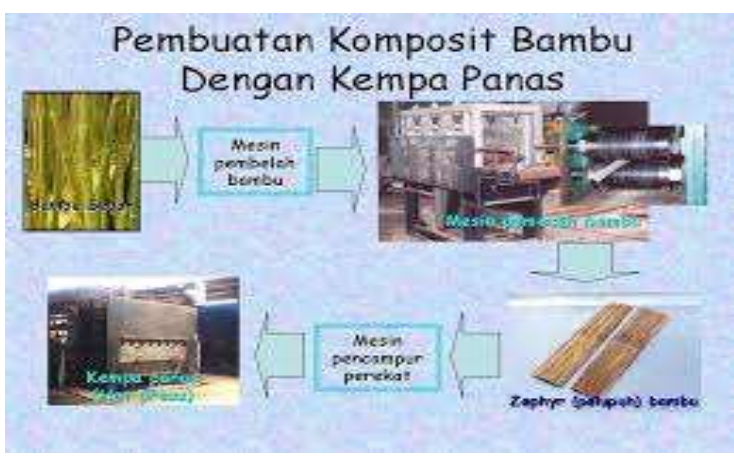

Gambar 4. Rekayasa material bambu

\section{HASIL DAN PEMBAHASAN}

Dalam konservasi cagar budaya dikenal dua prinsip utama yakni autentisitas dan reversibilitas. Auntentisitas adalah prinsip untuk melakukan sekecil-kecilnya treatmen untuk mempertahankan keaslian dari benda maupun bangunan cagar budaya, sementara itu reversibilitas adalah prinsip di mana setiap treatmen yang dilakukan dapat dihilangkan kembali sehingga benda atau bangunan tidak berubah penampilannya ketika treatmen dihilangkan. Oleh sebab itu, bahan-bahan alami dan cara-cara tradisional yang digali dari pengetahuan etnis-etnis di Indonesia menjadi cara yang patut untuk diperhitungkan dalam upaya konservasi kayu dan non kayu.

Indonesia sebagai salah satu 333 amboo yang berada di wilayah tropis serta kaya akan budaya memiliki banyak tinggalan- 
Volume 2, Nomor 1, Tahun 2020 Hal 330 - 338

tinggalan budaya material terutama benda atau bangunan yang terbuat dari kayu. Bila ditelusuri 334amboo seluruh etnis yang ada di Indonesia memiliki rumah tradisional yang terbuat dari kayu Akan tetapi dalam bentuk bangunan tradisional, kebanyakan bangunan tradisional yang menjadi cagar budaya terbuat dari kayu, seperti bagian-bagian tertentu dari bangunan kraton, masjid-masjid kuna, serta bangunan-bangunan tradisional etnis-etnis di Indonesia yang boleh dikatakan cukup tua, belum lagi berbagai benda dengan material kayu yang menjadi barang-barang etnik.

Bambu merupakan bahan alami yang sangat dipertimbangkan sebagai bahan bangunan non kayu di Indonesia. Namun, aplikasi 334amboo di dunia konstruksi belum banyak dijumpai. Salah satu penyebabnya adalah bentuk batang 334 amboo yang tidak 334amboo334ic. Bambu laminasi dapat digunakan sebagai solusi dalam mengatasi ketidak prismatisan batang. Bambu laminasi terbuat dari bilah-bilah 334amboo yang direkatkan dengan perekat sehingga mempunyai dimensi (panjang, lebar dan tinggi) yang ditentukan sesuai dengan kebutuhan. Berkaitan dengan hal tersebut maka dilakukanlah penelitian dan perancangan cold pressing mesin hidrolik 334amboo laminasi yang berfungsi sebagai alat untuk mencetak sekaligus penjepit dari bilah-bilah 334amboo tersebut. Hasil dari penelitian dan perancangan tersebut telah lolos uji kekuatan material dan lebih efisien, setelah dilakukan pengujian tersebut dapat disimpulkan cold pressing mesin hidrolik 334bamboo laminasi tersebut kuat dan lebih awet berdasarkan hasil uji tersebut lebih efisien, dan safety.

\subsection{Kelebihan bambu sebagai bahan} bangunan

1. Bambu melimpah dimana-mana sehingga murah dan mudah didapatkan dibandingkan material lain

2. Bambu sangat mudahdibudidayakan, dapat tumbuh pada daerah yang kurang baik, pertumbuhannya cepat dan umurnya pendek sehingga tidak perlu menunggu terlalu lama untuk memanen.

3. Tanaman bambu akan terus tumbuh melalui tunas-tunas baru setelah batang yang tua-tua ditebang, dan akan segera pulih kembali dalam waktu 1 tahun. Hal ini sangat berbeda dengan kayu yang membutuhkan waktu hingga 30 tahun untuk kembali menjadi hutan setelah ditebang.

4. Pengerjaannya mudah, praktis dan tidak memerlukan teknologi tinggi

5. Dapat digunakan dengan berbagai variasi kebutuhan,sehingga meski bahannya satu jenis namun dapat menghasilkan varian bentuk yang sangat beragam

3.2. Kelemahan bambu sebagai bahan bangunan 
Volume 2, Nomor 1, Tahun 2020 Hal 330 - 338

1. Bambu memiliki rongga di dalam batang dan beruas-ruas, sehingga mudah pecah karena kembang susut oleh perubahan cuaca, temperatur maupun kadar airnya. Untuk mengantisipasi hal ini material bambu perlu diawetkan sebelum digunakan, disamping hal tersebut kejadian bambu pecah ini akan sering kita jumpai terutama pada simpulsimpul pembebanan pada rangkaian struktur yang terbuat dari bambu, sehingga diperlukan modifikasi pada titik-titik simpul pembebanan dengan dilapis material logam. Sehingga pembagian beban lebih merata dan stabil

2. Bambu yang sudah terpasang sebagai material bangunan seringkali kita jumpai dimakan serangga bubuk/ngengat, sehingga diperlukan lapisan anti serangga.

3. Material bambu kurang tahan terhadap perubahan cuaca terutama yang terkena sinar matahari dan hujan secara langsung, sehingga perlu tindakan pengawetan dan setelah itu di coating agar bisa menghambat penyerapan air.

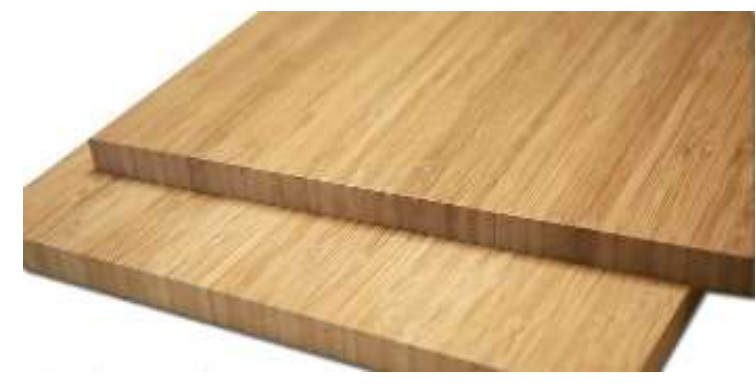

Gambar 5. Rekayasa bamboo board.

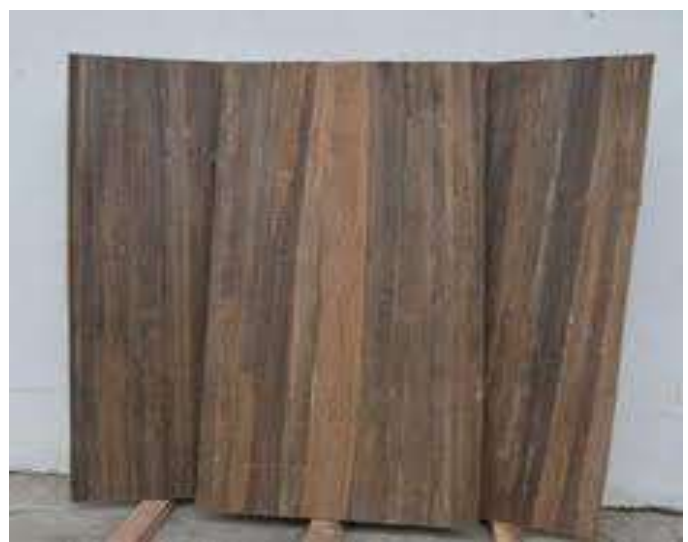

Gambar 6. Rekayasa Bambu zephyr

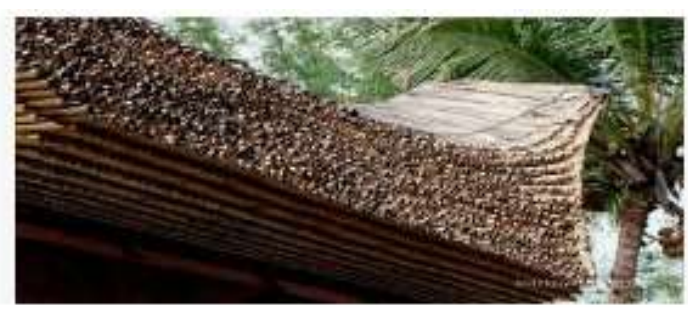

Gambar 7. Detail atap bambu
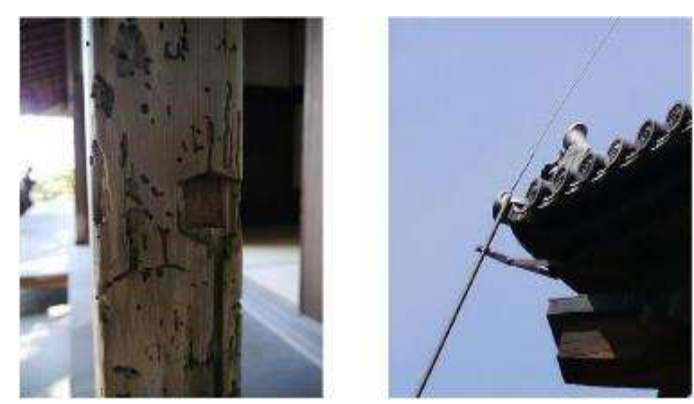

Gambar 8. Detail tiang kolom dan atap tongkonan 
Volume 2, Nomor 1, Tahun 2020 Hal 330 - 338

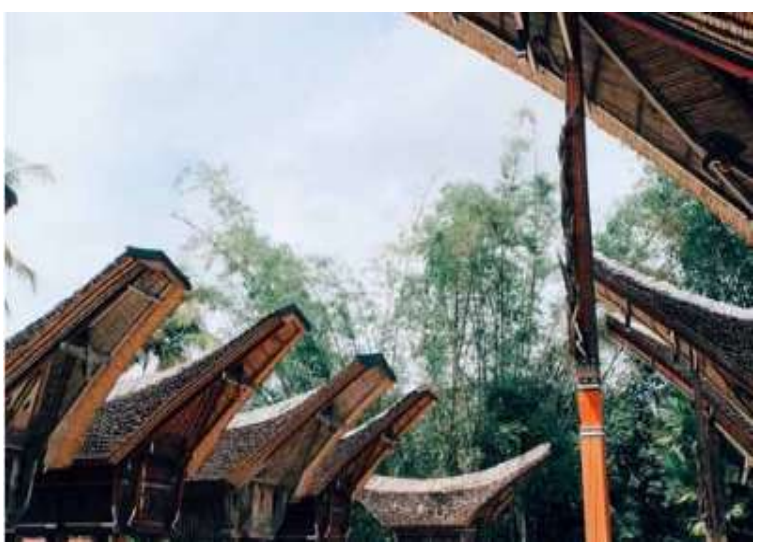

Gambar 9. Rumah tongkonan
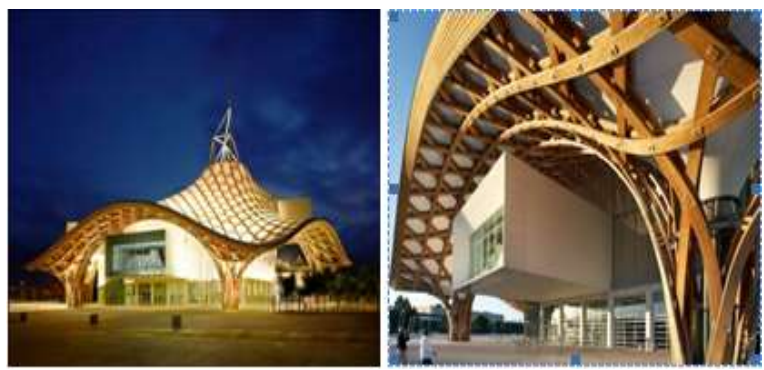

Gambar 10. Contoh rekayasa kayu laminasi untuk material rumah berbahan kayu

Perkembangan Lingkungan permukiman pada umumnya memberi dampak pada kurangnya habitat kehidupan hama rayap sehingga pola kehidupan rayap dapat menjelajah mencari makanan pokoknya pada bahan kayu (selulosa) yang terpasang pada konstruksi rumah penduduk dan rumah adat tongkonan.

Dengan pemanfaatan rekayasa material kayu pada bangunan khusus tongkonan dapat menyebabkan material rekayasa kayu kurang disukai sebagai bahan makanan pokok kehidupan koloni Rayap

\subsection{Bahaya rayap}

Sayangnya, kayu merupakan bahan organik yang tidak bisa bertahan lama. Apalagi di wilayah tropis seperti di Indonesia, kayu memiliki musuh utama yakni kelembapan dan serangga khususnya rayap yang menyebabkaN percepatan pelapukan terhadap kayu tersebut. Oleh sebab itu, sangat jarang tinggalan arkeologis ditemukan tinggalan arkeologis berbahan kayu yang telah berusia sangat tua

\subsection{Pengendalian bahaya rayap}

- Sebenarnya secara kimiawi dan modem, banyak metode yang dapat dilakukan dalam upaya mengkonservasi material kayu seperti penggunaan insektisida untuk membunuh rayap, menggunakan cat, pernis dan plitur, mengolesi material kayu dengan 'minyak tanah', 'solar', dan 'oli bekas'. Namun, hal tersebut sangat riskan diterapkan kepada benda atau bangunan cagar budaya.

- Penggunaan metode umpan pada lingkungan dalam dan luar bangunan ( Hexaflumuron )

\section{KESIMPULAN}

Pada penyuluhan di kota Rante Pao telah disampaikan bagaimana persiapan pemanfaatan material bambu dan material kayu waktu sebelum dan sesudah pembangunan rumah tongkonan dan rumah alang.Tujuan nya supaya keberadaan umur bangunan rumah tongkonan lebih lama dengan kondisi yang kuat dan tetap ber estetika. Begitupula lingkungan sekitar lingkungan rumah tongkonan dan rumah alang perlu dilakukan pekerjaan reboisasi 
Volume 2, Nomor 1, Tahun 2020 Hal 330 - 338 penanaman kembali bambu dan kayu sehingga mampu melestarikan kawasan rumah tongkonan secara berkelanjutannya. gagasan penggunan rekayasa material bambu dan rekayasa material kayu perlu dipertimbangkan secara serius yang didukung oleh regulasi oleh pemda toraja utara sehingga dapat mendukung dan melestarikan kawasan tongkonan tetap hijau

\section{RERERENSI}

Badan Standardisasi Nasional. 2003. SNI : Kumpulan SNI Perlindungan BangunanTerhadap Serangan Organisme Perusak. Badan Standardisasi Nasional. Jakarta

Forsythe, P. 2004. Pest Management

Practices for Home and Landscape : Subterranean Termite Control. Mississippi State University. (http://www.fwprdc.org.au)

Harris, W.V. 1971. Termites, Their Recognition and Control. Second Edition. Longmans. New York.

Haygreen, J.G. dan J.L. Bowyer. 1996. Hasil Hutan dan IImu Kayu. Gajah Mada University Press. Yogyakarta.

Khrisna, K. and F.M. Weesner. 1969. Biology of Termites. Vol I and II. Academic Press. New York. London. Kletch, S. 1996. Termite Control. Pest Control Technology No.24:46-52. USA.

Lee, K.E. and T.G. Wood. 1971. Termite and Soil. Academic Press. New York.
Leicester, R.H., C.H. Wang, L. Cookson dan J. Creffield. 2002. A Model of Termite for Hazard in Australia. CSIRO Building, Construction and Engineering. Australia. (www.landfood.unimelb.edu.au)

Morgan, E,D. 2004. Biosynthesis in Insects. The Royal Society of Chemistry. London.

Nandika, D., E.A. Husaini, S. Surjokusumodan D. Ngilly. 1994. A Survey on Termite Problems in The Low Cost Housing Compound of Jakarta and Its Vicinity. Symposium on Pest Ecology and Pest Management. Bogor.

Nandika, D., S. Surjokusumodan Y. Rismayadi. 1999. Status Bahaya Serangan Rayap pada Bangunan Gedung di Indonesia. Prosiding Seminar Nasional Pemantapan Pengendalian Rayap pada Bangunan Gedung. Jakarta.

Nandika D., Y. Rismayadidan F. Diba. 2003. Rayap : Biologi dan Pengendaliannya. Muhammadiyah University Press. Surakarta.

Pearce, M.J. 1997. Termite : Biology and Pest Management. Cab International. New York.

Prasetiyo, K.W. dan S. Yusuf. 2005. Mencegah dan Membasmi Rayap Secara Ramah Lingkungan dan Kimiawi. AgromediaPustaka. Jakarta. 
Volume 2, Nomor 1, Tahun 2020 Hal 330 - 338

Rachman, O. 2003. IlmudanTeknologi Pengolahan Hasil Hutan. Pusat Penelitian Hasil Hutan. Bogor.

Rismayadi, Y. 1999. Penelaahan Daya Jelajah dan Ukuran Populasi Koloni Rayap Tanah SchedorhinotermersjavanicusKemner Serta MicrotermesinspiratusKemner. Program Pascasarjana, IPB (tidakdipublikasikan). Bogor.

Surjokusumo, S. 2005. Perkembangan Aspek Regulasi Pengendalian Serangan Rayap padaBangunan Gedung. Seminar Nasional. Universitas Negeri Semarang. Semarang.

Tambunan, B. dan D. Nandika. 1989. Deteriorasi Kayu oleh Faktor Biologis. PAU Bioteknologi IPB. Bogor.

Tarumingkeng, R.C. 1971. Biologidan

Pengenalan Rayap Perusak Kayu Indonesia. Lap. Lembaga Penelitian Hutan No. 138. Bogor.

Tho, Y.P 1992. Termites of Peninsular Malaysia. Forest Research Institute Malaysia. Kepong, Kuala Lumpur. Anonymous (2007), Wood Handbook: Wood As an Engineering Material, Washington: US Dept. of Agriculture.

Cahyandaru, Nahar dkk, 2010. Konservasi Cagar Budaya Berbahan Kayu Dengan Bahan Tradisional. Balai konservasi Borobudur 